\title{
Why Teach in Prison: Co-Constructing the Prison Classroom
}

\author{
Mary Fainsod Katzenstein, Cornell University \\ Jill Frank, Cornell University
}

Teaching in prisons isn't revolutionary, but it's not nothing either. As American citizens, we are at our most complicit with mass incarceration when we allow the rigid barrier between the incarcerated and the free to stand unchallenged. By bridging these boundaries and by bringing incarcerated people into our institutional lives, we whittle away at the dehumanizing invisibility on which mass incarceration depends. Along the way, those who teach in prisons discover just how extraordinary these teaching experiences turn out to be.

-Joshua Dubler (http://rsn.aarweb.org/node/367)

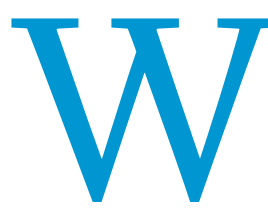

hy teach college classes in prison? While driving back from evening classes at Auburn Correctional, the answer seems simple: discussion usually ignites with the first question, moments of intellectual discovery are palpable, humor forges community. The deep satisfaction we derive from campus teaching is reproducedand then some-in the prison classroom.

Simultaneously, however, second-guessing easily sets in: Is the classroom a site of appeasement or defiance in the face of the unrelenting rules controlling college instruction in prison? As white women instructors, do we have a legitimate place in a classroom of mostly African American and Hispanic male students? As teachers in a maximum-security facility, are we truly agnostic when it comes to a readiness to work with students no matter what their crimes of conviction?

Our approach to these provocations emanates from our disinclination, in any context, to offer a monothematic perspective. Rather than staking out a declarative position on these questions, we sort through and acknowledge a range of the reflections we have heard, read, and voiced ourselves about the reasons why we and others commit to the prison classroom. Ultimately, we turn to how we experience our work with students who, in some cases, have been convicted of criminal acts that society brands as the "worst of the worst."

We borrow in format from an article by Barbara Babcock entitled, "Defending the Guilty' after 30 Years" (Babcock 2013). She enumerates a set of responses that public-defense lawyers provide to the inevitable question of "How can you defend someone you know is guilty?" Following Babcock's lead, we consider various kinds of reasons for prison teaching expressed by college-in-prison instructors, along with our own reasons for engagement with prison teaching. Some of these stem from our commitments to social justice, equal access to educational opportunity, and political activism. Others reflect our love of teaching and our belief in the capacity of classroom dialogue to co-create intellectual and personal insight into as well as out of the plural and complex ways of thinking of both students and teachers.

\section{UNIVERSAL HIGHER EDUCATION}

For a number of people drawn to prison teaching, the prison classroom represents a commitment to "College for All." Ellen Condliffe Lagemann, former dean of the Harvard Graduate School of Education and a participant in the Bard Prison Initiative, describes the expansion of higher education into prison-its benefit for society-as a natural extension of the broader democratic development of education. She cites the Degrees of Freedom study done at Stanford and Berkeley that included college in prison as part of a master plan for California education that incorporates college education in prison into the three-tier community college, state college, and research universities system in the state (Lagemann 2017, 184). By this argument, universal college education is a basic civil right that improves society and increases civic engagement.

\section{SOLIDARITY}

For some instructors-and particularly for some teachers of color as well as prison abolitionists of all backgrounds-the motivations and rewards of teaching are closely linked to a sense of solidarity with African American, Latino/a, American Indian, and low-income students in prison classes. This often is expressed as a sense of shared fate, as an embrace of extended kinship (virtual or otherwise), as recognition of collective resistance, and (pedagogically) as determination to give voice to those who-by virtue of isolation and socioeconomic inequality-are mostly silenced. The classroom under particular circumstances can be, according to Dylan Rodriguez (2005, 93), “...transformed, appropriated, or rearticulated by imprisoned radical and proto-radical intellectuals, who may galvanize new communities of solidarity or political kinship among and between course participants (including, at times, volunteer teachers, tutors, and teaching assistants from the free world)."

\section{DISSOLUTION OF THE CARCERAL STATE}

For some, college teaching is a route to the normative dismantling of the carceral state itself. Jody Lewen, executive director of the Prison University Program at San Quentin, proposes that college programs in prison have the capacity to 
"undermine the social and ideological underpinnings of the very practice of incarceration." They do so "...by challenging the culturally dominant belief systems that allow incarceration to appear morally legitimate, productive and rational." Lewen unpacks the ways that prison teaching, through the diffusion of counter-perspectives beyond the prison walls, helps to dissolve three ideological assumptions that sustain mass incarceration: "the concept of 'Bad People'-the idea that one 'ends up in prison' simply as a result of one's actions, and the notion that there are human beings who 'deserve to suffer"' (Lewen 2014, 353, 355). These ideological pillars of the carceral state are particularly susceptible to challenge, Lewen stipulates, by those who have seen the fallacy of these beliefs at close hand.

\section{MORAL/INDIVIDUAL TRANSFORMATION}

Although moral justifications for prison teaching have a long provenance dating to decades past (Justice 2000, 279-301), it is rarer to hear present-day teachers associate their role in the classroom with the goals of moral reform. Perhaps more commonly, instructors introduce issues about individual agency/ moral responsibility and ideas of structural responsibility as topics of textual battles and classroom debate (Karpowitz 2017, 78-9). However, a type of moralism clothed in the language of "transformation" often surfaces in conversations about prison education-rarely as the stated purpose of prison teaching but rather as an observed and sometimes celebrated outcome of the classroom experience. College-in-prison programs, knowing the resonance of this appeal with the public and donor communities, tout the impact of college education (via preparation for the job market and general maturation) on lowering recidivism. to the world of the Yard where social groupings are determined largely by race, status often depends on the nature of your crime (murderers rule, sexual offenders are fair game), and survival may require affiliation with a gang, and the consequent obligation to prove your manhood, risking serious injury and the extension of your sentence, by engaging in violence.

The classroom can be an opportunity, then, where a second self can at least temporarily find its place-a place, in TW's words, to "fortify and deepen each student's inner realm, which prison otherwise threatens to invade and occupy."

\section{HUMAN CAPACITY}

A core motivation shared by many prison instructors is the hope of assisting students in acquiring and honing intellectual and critical capacities. Philosopher Martha Nussbaum defines the essence of humanity or personhood as consisting of 10 "central capabilities." Following "life," "bodily health," and "bodily integrity," she specifies a fourth capability as the basic individual capacity to "imagine, think, and reason" (Nussbaum 2013, 32-4). It is common to hear prison instructors comment on the profound satisfaction of observing and participating in the experience of a student whose discovery of intellectual potential yields a newly found sense of intellectual confidence. For many prison instructors, supporting such human capabilities is central to the mission of prison instruction.

\section{EGOTISM}

Inevitably, self-affirmation is part of what instructors seek-and receive-in the prison classroom. Feeling useful as a teacher materializes quickly in a setting where formal learning is a

\section{The satisfaction we derive from what we think of as the co-construction of the learning process occurs through a reconfiguration of the binary of student "learning" and/or instructor "teaching." It occurs when the classroom experience creates a "third thing"- namely, a forging of ideas, insights, and desires that belongs not to any classroom participant alone but to the space between student and student and teacher and students.}

\section{LIBERATORY SPACE}

For some prison instructors, a preeminent argument for prison teaching may rest less with the broader societal purposes of prison instruction than with the more "presentist" hope of "smuggling into the classroom a little bit of freedom," as our colleague TW observed in conversation. Pete Wetherbee (2008), one of the founders of the Cornell Prison Education Program, wrote that

No inmate in a maximum security facility...can avoid the necessity to live a divided existence, to be in effect two people. The private world (in the severely limited sense that term can have for a prison inmate) in which he ${ }^{1}$ may be a devout and observant Christian or Muslim, an aspiring poet or essayist, a conscientious advisor by mail to sons or nephews, bears virtually no relation scarce commodity and entitlement is absent. First-time teachers invariably comment on the vibrant student engagement in prison classes, as well as the intellectual stimulation and exhilaration they experience responding to the multiplicity of challenging questions that may differ from those they hear in their campus classrooms.

\section{CO-CONSTRUCTING THE PRISON CLASSROOM}

Our own involvement in prison teaching draws on all of these reasons. It is, however, the co-immersion with students in the production of ideas in the classroom that matters more for us than many of the other compelling arguments for prison teaching. The satisfaction we derive from what we think of as the co-construction of the learning process occurs through a reconfiguration of the binary of student "learning" and/or 
instructor "teaching." It occurs when the classroom experience creates a "third thing"-namely, a forging of ideas, insights, and desires that belongs not to any classroom participant alone but to the space between student and student and teacher and students. It is this teaching "with" rather than teaching "to" that draws us to the prison classroom.

The disparity in academic learning or educational background between teacher and students in any classroom can seem to be an obstacle to the joint creative work that fuels this co-construction. To be sure, a teacher may know a text better and may have more information at her disposal about the topic under discussion. Yet, a teacher's account is only learnable if it is persuasive-and, to be persuasive, it must be persuasive to her students.

In this way, we ally ourselves with the pedagogical commitment to collective learning embraced by Paolo Freire's Pedagogy of the Oppressed. In consonance with Freire but in Simone Weil Davis's $(2013,164)$ words, this is a commitment to

$$
\begin{aligned}
& \text {...not only far greater access to education but also its radical } \\
& \text { reconceptualization: a redefinition that emphasizes community } \\
& \text { creation and collective purpose rather than individual self- } \\
& \text { 'betterment' and 'upward' mobility, one that turns literacy from } \\
& \text { a noun to a verb, from a possession one acquires and owns into a } \\
& \text { practice between people. }
\end{aligned}
$$

Still, we speak here in a different register of time, in a phenomenology of the now that is somewhat different from Freire's. Our thoughts about the "practice between people" are in the context of the immediacy of the classroom. Our concern is with the space of freedom and equality that is co-created in the "here and now" rather than with future efficacy or outcomes for the body of incarcerated students about which we are not in a position to conjecture.

The co-construction in and of the classroom emanates through both process and substance: processually, through the paying of mutual respect, of circulating authority, of sharing humor, of making space for both anger and comity; perhaps one or two incidents can be suggestive. One occurred a while ago as the next-to-final session of the semester approached in a class that one of us co-taught. Student-paper presentations were scheduled in no preset order. It quickly became clear that everyone in the class had presented except one student, who had rarely spoken in class-although he was diligent, his written work was good, and he was communicative in one-on-one situations. With only two students left to present, prospective humiliation loomed. As teachers, we might have anticipated this situation. We had not. Another student in the class took the lead, thumping on his desk and calling his colleague's name. Others joined in immediately. The quiet student smiled, moved to the front of the class, delivered his presentation, and an animated discussion followed.

More recently, a colleague, Jan Zeserson, was involved in a research seminar in a facility that brought Cornell faculty in to engage with seminar students writing papers of their own. Faculty were invited to discuss their research and students were urged to probe them in ways that could be helpful to their own work in progress using the following four-part question format: (1) When you said this, (2) It made me think of this, (3) The reason I thought of this is because I have had this experience or seen in my own reading, (4) And because I have had this experience, I would like to ask you this question. By referencing their own knowledge and drawing on investments in their own topics, the students joined the visiting faculty in a process that placed student and faculty on a plane of co-engagement.

These moments offer experiences of both capacitation and connection that we seek in any classroom. They acquire a heightened intensity in the prison classroom for two reasons: (1) the structural juxtaposition between the hierarchical, oppressive, and stultifying confinement of the prison and the openness of and distribution of agency in the classroom; and (2) the dramatic differences (of experience, identity, personality) that inform the classroom conversation. In a place where life is grievously constricted and antagonisms are ubiquitous, it is a profound experience for us as teachers to be party to the

\section{They acquire a heightened intensity in the prison classroom for two reasons: (1) the structural juxtaposition between the hierarchical, oppressive, and stultifying confinement of the prison and the openness of and distribution of agency in the classroom; and (2) the dramatic differences (of experience, identity, personality) that inform the classroom conversation.}

and, substantively, through the interactive exploration of ideas that can be uncomfortable and may come to be mutually understandable. At its most challenging, co-construction involves the unmapped moments in which interventions can turn out to be generative or silencing, encouraging or even degrading.

These moments are more easily "defined" than they are illustrated. A single example or two cannot begin to carry the weight of exemplifying the process of co-construction, but relatively freer and more equal thinking in common that students and teachers seek together in the classroom.

The prison classroom is different in yet another way, for it may entail working with students who have been involved in violent crimes that caused tragic injury and death to others. For one of us, this presents no reason not to be part of the process of instruction. We are there to learn and to teach, not to judge. For the other, judgment seems inevitable. For both of us there is the recognition that in our humanity, we are all 
made of "many parts." As the Canadian attorney and writer, Rupert Ross $(1996,109)$, reflected:

...I shudder when I see headlines screaming 'Get Tougher on Those Offenders!' I don't know how to lock up and torture only the ugly 'offender-parts' of people, while comforting the hurt parts, teaching the curious parts, nursing the starved parts, unearthing the hidden parts, emboldening the cautious parts and inspiring the dreaming part.

As teachers and learners, we also come to the prison classroom with and in our many parts-curious, apprehensive, cautious, ambitious, privileged, self-serving, burdened by our own regrets-and, above all, wanting intently to join with the intersecting parts of others to co-create human possibility and to co-realize human potential.

\section{ACKNOWLEDGMENT}

For their good advice, we are grateful to Lawrence Glickman, Peter Katzenstein, Suzanne Katzenstein, Jamila Michener, Molly Shanley, Alison van Dyke, and Jan Zeserson.

\section{NOTE}

1. Wetherbee was writing about an all-male facility, Auburn Correctional in New York State.

\section{REFERENCES}

Babcock, Barbara A. 2013. "'Defending the Guilty' after zo Years." In How Can You Represent Those People?, eds. Abbe Smith and Monroe Freedman, 1-13. New York: Palgrave Macmillan.

Davis, Simone Weil. 2013. "Inside-Out: The Reach and Limits of a Prison Education Program." In Turning Teaching Inside Out: Community Engagement in Higher Education, eds. Simone Weil Davis and B. S. Roswell, 163-75. New York: Palgrave Macmillan.

Justice, Benjamin. 200o. "A College of Morals": Educational Reform at San Quentin Prison, 1880-1920. History of Education Quarterly 40 (3) 279-301.

Karpowitz, Daniel. 2017. College in Prison: Reading in an Age of Mass Incarceration. New Brunswick, NJ: Rutgers University Press.

Lagemann, Ellen Condliffe. 2017. Liberating Minds: The Case for College in Prison. New York: The New Press.

Lewen, Jody. 2014. "Prison Higher Education and Social Transformation." Saint Louis University Public Law Review 33: 353-355.

Nussbaum, Martha. 2013. Creating Capabilities: The Human Development Approach. Cambridge, MA: Harvard University Press.

Rodriguez, Dylan. 2005. Forced Passages: Imprisoned Radical Intellectuals and the US Prison Regime. Minneapolis: University of Minnesota Press. Available at https://circuitdebater.wikispaces.com/file/view/Dylan Rodriguez-Forced_Passages__Imprisoned_Radical_Intellectuals_and_ the_US_Prison_Regime.

Ross, Rupert. 1996. Returning to the Teachings: Exploring Aboriginal Justice. Toronto: Penguin Canada.

Wetherbee, Winthrop (Pete). 2008. "Cornell at Auburn: An Experiment in Teaching and Learning." Cornell University: Department of English. Available at http://cpep.cornell.edu/home/wp-content/uploads/2013/o9/ Wetherbee-2008.pdf. 